\title{
基于空间聚类的中国东北气候分区及其 气象干旱时间变化特征
}

\author{
李 明 ${ }^{1,2,3}$, 王贵文 ${ }^{1}$, 柴旭荣 ${ }^{1}$, 胡炜霞 ${ }^{4}$, 张莲芝 ${ }^{1}$ \\ (1. 山西师范大学地理科学学院, 临汾 $041000 ; 2$. 山西师范大学现代文理学院, 临汾 $041000 ; 3$. 山西师范 \\ 大学遥感与气候信息实验室,临汾 $041000 ; 4$. 山西师范大学历史与旅游文化学院,临汾 041000)
}

\begin{abstract}
摘要：近 50 年来, 中国东北地区干旱化趋势明显, 越来越频繁的干旱事件对该区域人民的生产 和生活造成了严重的影响。基于 1961-2016年中国地面降水和气温月值 $0.5^{\circ} \times 0.5^{\circ}$ 格点数据, 利 用空间系统聚类方法对中国东北进行气候分区, 通过标准化降水指数探讨了中国东北各亚区 气象干旱的时间演变规律, 并结合小波功率谱和小波全谱分析了各亚区干旱的周期变化特 征。结果表明: (1)空间上, 可将东北地区分为 8 个气候亚区, 即西辽河平原半干旱农牧区、吉辽 东部山地湿润农林区、呼伦贝尔高原半干旱牧业区、东北中部半湿润一半干旱农牧区、黑吉东 部山地湿润农林区、大兴安岭北部湿润林业区、呼伦贝尔一黑河湿润一半湿润农林区、三江平 原湿润农业区; (2)不同亚区的干旱事件时间演变特征存在明显差异, 但大致都经历了 3 个干旱 时期: 1960s 后期、1970s 中后期至 1980s 前期、1990s 后期至 2000s; 2000-2010年间东北地区干旱 发生频率和影响范围最大, 尤其是中、西部; (3)不同亚区干旱变化主要存在 11 年和 3 8 年的显 著周期, 第一主周期差异明显。研究结果对于弄清楚中国东北各亚区特有的气候变化驱动因 素、制定气候均质区域干旱监测计划和水资源的管理具有重要的现实意义。
\end{abstract}

关键词: 气候分区;气象干旱;标准化降水指数;空间系统聚类;小波分析

干旱是一种经常出现的极端气候事件, 通常是指在某一时间段内降水量低于正常年 份的降水量, 它是一种暂时的气候现象, 不同于干旱区的永久性干旱。IPCC第五次研究 报告指出：在北半球，1983-2012 年可能是最近 1400年来气温增幅最快的时期 ${ }^{[1]}$ 。在全球 增温的背景下，中国东北地区（Northeast China，NEC）近 50 年来表现出明显的暖干化 趋势 ${ }^{[2-3]}$, 尤其是 $1990 \mathrm{~s}$ 以后干旱发生的频率和强度增加显著 ${ }^{[4-5]}$, 已经严重影响到该区域的 农业生产和国家粮食安全。因此, 许多学者对 NEC干旱变化的时空特征进行了研究 ${ }^{[2-6]}$, 不 过, 多数研究是以 NEC 干旱的整体变化趋势和生长季的变化特征为研究对象 ${ }^{[2-3,6]}$, 而 NEC 由于地形复杂, 气候条件和敏感性在不同的区域差异很大, 将 NEC 作为单一的研究 区域，无法揭示该区域内部的干旱变化。为了了解 $\mathrm{NEC}$ 气候敏感区的空间格局和揭示不 同地区、不同季节的气候变化驱动因素及其未来潜在的变化，有必要进行区域的空间细 分。已有部分学者依据气象站点数据对 NEC 的气候分区进行了探索性研究, 如孙力等 ${ }^{[7]}$ 将 NEC 分成了 7 个气候亚区, 并分析了各气候亚区地表的干旱状况。孙滨峰等 ${ }^{[8]}$ 依据 NEC1961-2013 年的月均温和月降水数据，结合主成分分析和聚类分析方法将 NEC 分为 8 个气候亚区，分别探讨了各个亚区干旱事件的时间演变特征。李明等 ${ }^{[9]}$ 借助旋转正交函数

收稿日期：2018-11-13; 修订日期：2019-05-07

基金项目：国家自然科学基金项目（41501160，31571604); 山西省高校科技创新项目（20161113）

作者简介: 李明 (1982- ), 男, 河南商丘人, 副教授, 主要从事区域气候变化方面的研究。E-mail: 1 lim489@163.com 通讯作者：柴旭荣（1975- ), 男, 山西临汾人, 副教授, 主要从事资源环境遥感研究。E-mail: chaixurong@163.com 
分解方法将 NEC 分为 5 个气候区，并分析了各个亚区的干早化趋势及其突变时间。然 而, 由于这些学者使用的是气象站点数据，对 NEC 进行气候分区时存在气候亚区的划分 没有明确界线 ${ }^{[10]}$ 、气象站点分布不均带来的精度等问题 ${ }^{[1]}$ 。

基于上述原因，本文以中国地面降水和气温月值 $0.5^{\circ} \times 0.5^{\circ}$ 格点数据为数据源，利用 空间系统聚类分析对 NEC 进行气候分区，而后基于标准化降水指数（Standardized Precipitation Index，SPI）探讨各气候亚区气象干旱的时间演变规律，并结合小波方法分析 各亚区气象干旱的周期变化特征，以期为 NEC气候均质区域干旱监测计划的制定和水资 源的管理提供理论依据。

\section{1 研究方法与数据来源}

\section{1 研究区概况}

东北地区位于 $115^{\circ} 52^{\prime} \sim 135^{\circ} 09^{\prime} \mathrm{E} 、 38^{\circ} 72^{\prime} \sim 53^{\circ} 55^{\prime} \mathrm{N}$ ，行政区上辖东北三省（黑龙江 省、吉林省和辽宁省）及内蒙古东部三市一盟（赤峰市、通辽市、呼伦贝尔市和兴安 盟), 面积约 $1.24 \times 10^{6} \mathrm{~km}^{2}$ (图 1)。NEC 地形复杂, 大、小兴安岭和长白山分列其中。气 候类型属于温带大陆性季风气候，降水量集中在夏季，且空间分布不均，自东南向西 北，年均降水量从 $1032.8 \mathrm{~mm}$ 下降至 $230.6 \mathrm{~mm}$ 。南北跨纬度大，包括暖温带、温带和寒 温带，自南向北，年均温从 $12.4{ }^{\circ} \mathrm{C}$ 下降至 $-7.0{ }^{\circ} \mathrm{C}$ 。

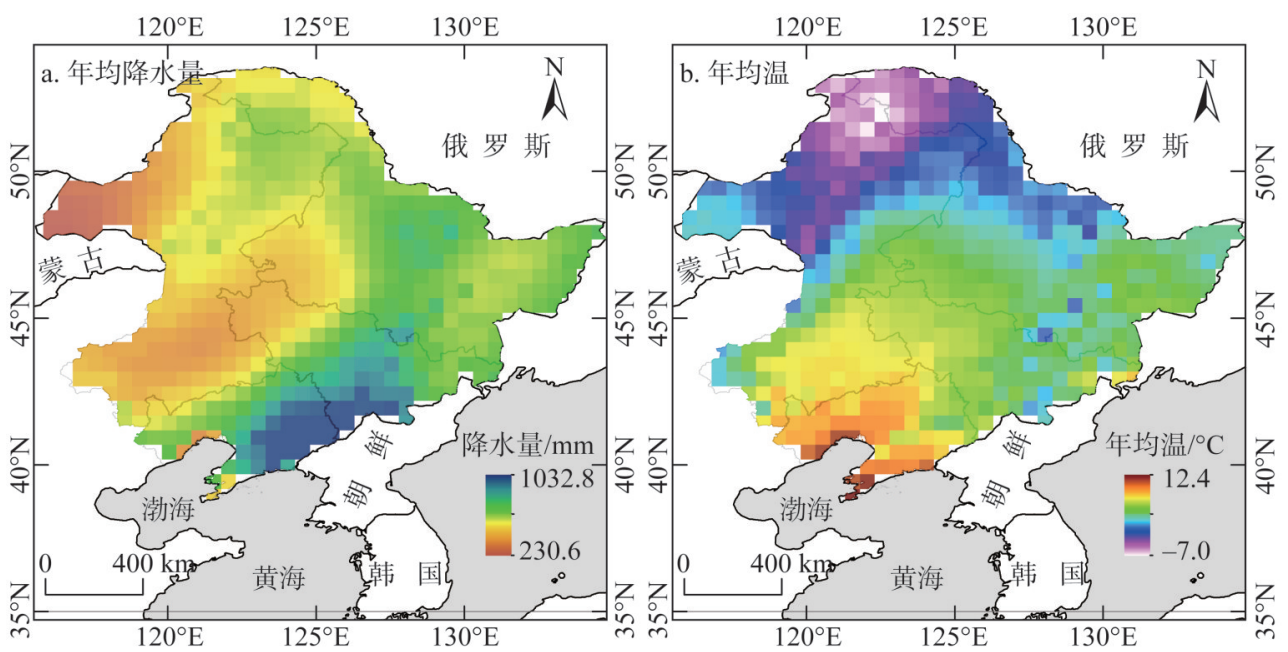

图 1 1961-2016年年均降水量和年均温空间格局

Fig. 1 Spatial pattern of annual precipitation and annual mean temperature in Northeast China from 1961 to 2016

\section{2 数据来源}

研究区 1961-2016年的降水和气温格点数据来源于中国气象数据网（http://data.cma. $\mathrm{cn} /)$, 空间分辨率： $0.5^{\circ} \times 0.5^{\circ}$ 。该数据集经交叉验证和误差分析，质量状况良好，降水和 气温的误差分别为 $0.49 \mathrm{~mm} /$ 月和 $0.24^{\circ} \mathrm{C} /$ 月 $^{[11-13]}$ 。图 1 为利用该资料计算得到的 $\mathrm{NEC}$ 多年 平均降水量和多年年均温分布图, 共 575 个格点。

\section{3 研究方法}

\subsection{1 空间系统聚类}

气候分区研究，实质上就是将具有气候特征相似且空间上连续的区域聚合在一起， 
是聚类方法在地理空间上的应用。本文借助 $\mathrm{R}$ 软件中的 HiClim R 统计包 ${ }^{[14]}$, 采用空间系 统聚类方法，以1961-2016年的年降水量和年均温为输人数据，对 NEC 进行气候分区。 为了消除量纲的影响, 本文对 NEC 各有效格点的年降水量和年均温进行了标准差标准化的 预处理。另外，在全球气候变化的背景下，NEC不同格点的年降水量和年均温的变化趋势 是不一致的，且趋势的存在会导致区域之间相关性的增加，不利于气候亚区的划分 ${ }^{\left[{ }^{[14]}\right.}$, 故本文对 NEC 各格点进行了去趋势处理。聚类过程中采用皮尔逊相关系数计算点与点之 间的距离，利用离差平方和法（ward法）计算类与类之间的距离，通过同时最小化区域 间相关系数和最大化区域内相关系数判定区域的邻接关系和均质性。

\subsection{2 标准化降水指数}

1993 年 McKee 等 ${ }^{[15}$ 提出的 SPI，能够将降水时间序列转化为与降水发生概率相关的 标准化值, 消除降水量在时空分布上的差异。因此, 通过 SPI值可以比较不同区域、不同时 间尺度的旱涝情况。SPI 的具体计算步骤参见《气象干旱等级 (GB/T20481-2006T)》 ${ }^{[16]}$, 干旱等级的划分见表 1 。本文选取 12 个月时间尺度的 SPI (SPI-12) 分析 NEC 气候亚区的干 旱情况, 因为该时间尺度可以反映干旱的年际变化, 更适合确定干旱期的持续性 ${ }^{[17-18]}$, 并 能够消除季节变化的影响 ${ }^{[19-20]}$ 。虽然干旱的季节性变化也是干旱评估的一个重要问题，但 这不是本文讨论的重点。

\section{表 1 依据 SPI 的干旱等级划分}

Table 1 Drought categories according to SPI value

\begin{tabular}{cccccc}
\hline 干早等级 & 无旱 & 轻旱 & 中旱 & 重旱 & 特旱 \\
\hline SPI值 & $(-0.5,+\infty)$ & $(-1.0,-0.5]$ & $(-1.5,-1.0]$ & $(-2.0,-1.5]$ & $(-\infty,-2.0]$ \\
\hline
\end{tabular}

\subsection{3 小波分析}

小波是具有零均值且可以在频率域与时间域内进行局部化的数学函数 ${ }^{[21]}$ 。由于 Morlet 小波能够很好地平衡时间与频率的局部化 ${ }^{[22]}$, 故本文选取 Morlet 为母小波, 其定义为:

$$
\psi_{0}(\eta)=\pi^{-1 / 4} e^{i \omega_{0} \eta} e^{-\eta^{2} / 2}
$$

式中： $\eta$ 为无量纲化时间； $\omega_{0}$ 是无量纲化频率。当 $\omega_{0}=6$ 时，小波尺度 $s$ 与傅里叶周期 $\lambda$ 大 致相等 $(\lambda=1.03 \mathrm{~s})$, 这样小波尺度就可以与小波周期相互替代 ${ }^{[21]}$ 。本文将对 NEC 各气候 亚区 SPI-12 时间序列进行 Morlet 小波变换，探讨各亚区气象干旱的周期特征。

\section{2 结果分析}

\subsection{NEC 气候分区}

考虑到地形的基本特征以及区域的连续性、独立性，最终将 NEC 划分成 8 个气候亚 区 (图 2)。

（1）西辽河平原半干早农牧区（I ）。该区域主要包括内蒙古赤峰市、通辽市以及辽 宁省的西部, 以农田和草地为主, 共 84 个格点, 总面积约 $1.97 \times 10^{5} \mathrm{~km}^{2}$ 。区域内年降水 量约 $435.6 \mathrm{~mm}$, 年均温约 $6.36{ }^{\circ} \mathrm{C}$ 。该区域是干旱的高发区域, 以中度干早为主, 其中春 季干旱发生率高 ${ }^{[8]}$ 。

（2）吉辽东部山地湿润农林区（II）。该区域主要包括辽宁省东部和吉林省东南部, 以森林和农田为主, 共 47 个格点, 总面积约 $1.16 \times 10^{5} \mathrm{~km}^{2}$ 。年降水量约为 $796.0 \mathrm{~mm}$, 年 
均温约 $6.42{ }^{\circ} \mathrm{C}$ 。该区域属于湿润气候区, 是 $\mathrm{NEC}$ 的多雨中心。

（3）呼伦贝尔高原半干旱牧业区（III）。 该区域主要包括内蒙古呼伦贝尔市西部，属于 中温带大陆草原气候，植被是以羊草和针茅为 主的草甸草原和典型草原，共47个格点，面积 约 $9.59 \times 10^{4} \mathrm{~km}^{2}$, 是 $\mathrm{NEC}$ 的生态脆弱区。年降 水量约 $356.9 \mathrm{~mm}$, 年均温约 $-1.26{ }^{\circ} \mathrm{C}$ 。该区域 处于大兴安岭的背风坡, 降水较少, 属于半干 早区, 但由于气温偏低, 蒸发较弱, 空气湿度 仍然偏高 ${ }^{[23]}$ 。

(4) 东北中部半湿润一半干早农牧区 (IV)。该区域主要包括内蒙古兴安盟、吉林省 中西部以及黑龙江省的西南部, 以草地和农田 为主, 共 116 个格点, 面积约 $2.50 \times 10^{5} \mathrm{~km}^{2}$, 是 $\mathrm{NEC}$ 主要的粮食产区, 同时也是农业生态环境 破坏最严重的区域。该区域水汽来源缺乏, 降 水量较少, 约 $476.5 \mathrm{~mm}$, 同纬度上降水量由 东向西减少 ${ }^{[23]}$, 年均温约 $3.98{ }^{\circ} \mathrm{C}$ 。

（5）黑吉东部山地湿润农林区（V)。该区

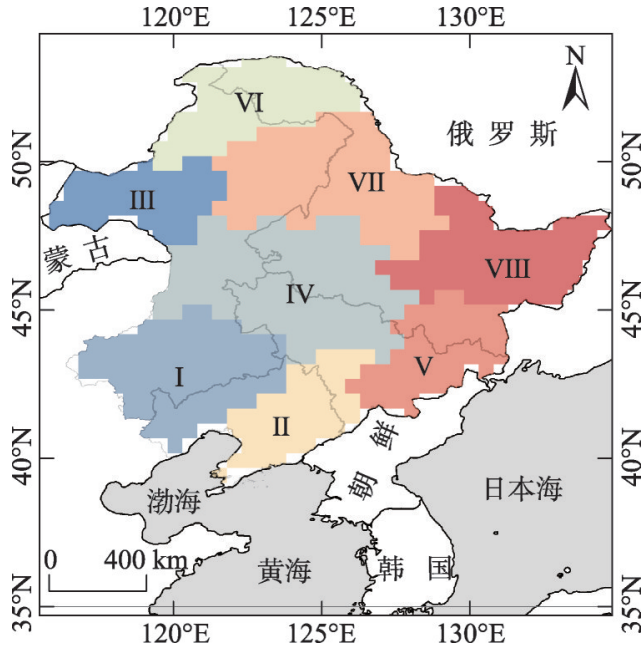

注：I 为西辽河平原半干旱农牧区; II 为吉辽东 部山地湿润农林区; III 为呼伦贝尔高原半干旱牧业 区; IV 为东北中部半湿润一半干旱农牧区; $V$ 为黑吉 东部山地湿润农林区; VI 为大兴安岭北部湿润林业 区; VII为呼伦贝尔一黑河湿润一半湿润农林区; VIII为 三江平原湿润农业区。

图 2 中国东北气候分区

Fig. 2 Climate regionalization in Northeast China 域主要包括吉林省东部和黑龙江省东南部的山区，以森林和农田为主，共 53 个格点, 面积 约为 $1.19 \times 10^{5} \mathrm{~km}^{2}$ 。年降水量约 $643.4 \mathrm{~mm}$, 年均温约 $2.80{ }^{\circ} \mathrm{C}$ 。当夏季盛行东南季风时, 在 长白山脉的迎风坡降雨量会远多于同纬度的西部地区。长白山区自 1970s 年均温稳定增 加，年降水量自 1990s 有减少趋势，而后进人到暖干化的过程 ${ }^{[9]}$ 。

（6）大兴安岭北部湿润林业区（VI）。该区域主要包括黑龙江省大兴安岭地区和内蒙 古呼伦贝尔市的北部, 以森林为主, 共 59 个格点, 面积约 $1.16 \times 10^{5} \mathrm{~km}^{2}$ 。该区域属于寒温 带大陆性气候, 受季风雨带影响较小, 温度较低, 蒸发量少, 年均降水量约 $470.5 \mathrm{~mm}$, 年均温 $-4.32{ }^{\circ} \mathrm{C}$ 。

（7）呼伦贝尔一黑河湿润一半湿润农林区（VII）。该区域主要包括黑龙江省的黑河市 和内蒙古呼伦贝尔市的东部, 共 95 个格点, 面积约 $1.91 \times 10^{5} \mathrm{~km}^{2}$ 。区域内森林覆盖率较 高，年降水量约 $531.8 \mathrm{~mm}$ ，年均温约 $-0.18{ }^{\circ} \mathrm{C}$ 。

（8）三江平原湿润农业区（VIII）。该区域主要包括黑龙江省的伊春市、鹤岗市、双鸭 山市、鸡西市、七台河市和佳木斯市, 共 74 个格点, 面积约 $1.56 \times 10^{5} \mathrm{~km}^{2}$ 。年降水量约 $569.3 \mathrm{~mm}$, 年均温为 $2.50{ }^{\circ} \mathrm{C}$ 。由于日本海和鄂霍次克海潮湿气流的影响, 加上沼泽和湿 地的作用，使得该区夏季降水比同纬度的松嫩平原明显偏多 ${ }^{[9]}$ 。但自 60 年代至今，干旱 化趋势增长迅速 ${ }^{[24]}$ ，尤其三江平原地区夏季降水减少趋势最为明显 ${ }^{[25]}$, 另外, 沼泽湿地 开脣后土壤热量条件发生巨大变化，也进一步加强了增暖效应 ${ }^{[26]}$ 。

表 2 为 NEC 各气候亚区组间及组内相关系数, 各组内格点的平均相关系数几乎都在 0.8 以上, 达到了 $\alpha=0.01$ 极显著水平, 组间相关系数相对较小, 说明利用空间系统聚类法 对 NEC 进行气候分区具有很好的分离性。另外, 相邻的亚区相关系数较高, 不相邻的亚 
表 2 NEC 各气候亚区组间/组内相关系数

Table 2 Inter-group/intra-group correlation coefficients for climate sub-regions in Northeast China

\begin{tabular}{|c|c|c|c|c|c|c|c|c|}
\hline 亚区 & I 区 & II 区 & III 区 & IV 区 & V区 & VI区 & VII 区 & VIII 区 \\
\hline I 区 & 0.80 & & & & & & & \\
\hline II 区 & 0.58 & 0.87 & & & & & & \\
\hline III 区 & 0.29 & 0.05 & 0.87 & & & & & \\
\hline IV 区 & 0.65 & 0.39 & 0.57 & 0.81 & & & & \\
\hline V区 & 0.25 & 0.45 & -0.03 & 0.31 & 0.82 & & & \\
\hline VI区 & 0.01 & 0.01 & 0.55 & 0.21 & -0.14 & 0.83 & & \\
\hline VII 区 & 0.30 & 0.07 & 0.66 & 0.70 & 0.12 & 0.65 & 0.79 & \\
\hline VIII 区 & 0.22 & 0.23 & 0.26 & 0.53 & 0.51 & 0.13 & 0.52 & 0.83 \\
\hline
\end{tabular}

注：对角线数字为各分区的组内相关系数，其余数字为各分区的组间相关系数。

区相关系数很小，也反映出气候变化在区域上的连续性。尽管 III 区、VI区与 VII 区的相关 系数均超过了 0.6 , 但考虑到它们在地形和植被覆盖上的差异，本文将其进行了分区。

\section{$2.2 \mathrm{NEC}$ 气候亚区干湿事件时间演变特征}

表3 表明：1961-2016年间，V 区干旱事件发生次数最多（28次），I 区干旱次数最 少 (15 次)，但 $\mathrm{V}$ 区平均干旱历时最短（7.5 月)，平均干旱烈度最小 (8.49)，I 区平均 干旱历时最长（13.87月），平均干旱烈度最大（15.99）。各个亚区中旱级别的事件发生 都比较频繁，其中 I 区最多（85月）。I 区、V 区、VI区、VII区特早发生月份相对较 多, 分别为 18 月、 11 月、 13 月和 14 月，而VIII区的重旱发生月份最多，为 42 月。

图 3 为 NEC 各气候亚区 SPI-12 序列的时间演变图，每个亚区的 SPI-12 时间序列是由 该区域平均月降水量计算而得。结果表明各气候亚区存在干旱和湿润时期的更替，但没 有固定的年际变化。I 区 1960s 中后期至1970s 初期经历了最频繁的低强度的干旱，其次 是 1970s 末期至 1980s 初期，1999年以后发生了最严重的干早。II 区是东北最为湿润的地 区，共发生 20 次干旱事件，但大多数为低强度的干旱，最严重的干旱发生在 2000s 前 后，其次是 2014-2016年。1965 年以前、1980s 和 1990s 中期、2010-2013 年为相对湿润 期，1998年特大洪水对该区影响较小。总体来看，1990s 以后该区重旱、特旱事件增加 明显。III 区共发生了 20 次干旱事件，其中最频繁、最严重的是 1999-2011 年间, 其次是 1960s 中期至 1970s 初期。相比之下，1980s 和 1990s 期间较湿润。IV 是 NEC 主要的粮食产

\section{表 3 NEC 气候亚区干旱指标统计}

Table 3 Basic statistics of droughts for climate sub-regions in Northeast China

\begin{tabular}{lcccccccc}
\hline 干早指标/亚区 & I 区 & II 区 & III & IV 区 & V区 & VI区 & VII区 & VII 区 \\
\hline 轻早/月 & 86 & 102 & 104 & 113 & 92 & 73 & 114 & 75 \\
中旱/月 & 85 & 65 & 50 & 65 & 71 & 62 & 50 & 69 \\
重旱/月 & 19 & 30 & 39 & 37 & 36 & 30 & 29 & 42 \\
特旱/月 & 18 & 4 & 4 & 8 & 11 & 14 & 13 & 5 \\
总干旱历时/月 & 208 & 201 & 197 & 223 & 210 & 179 & 206 & 191 \\
平均干旱历时/月 & 13.87 & 10.05 & 9.85 & 11.15 & 7.50 & 10.53 & 9.81 & 11.94 \\
总干旱烈度 & 239.95 & 218.02 & 214.96 & 240.91 & 237.77 & 215.44 & 227.27 & 222.23 \\
平均干旱烈度 & 15.99 & 10.90 & 10.75 & 12.05 & 8.49 & 12.67 & 10.82 & 13.89 \\
干早频次 & 15 & 20 & 20 & 20 & 28 & 17 & 21 & 16 \\
\hline
\end{tabular}




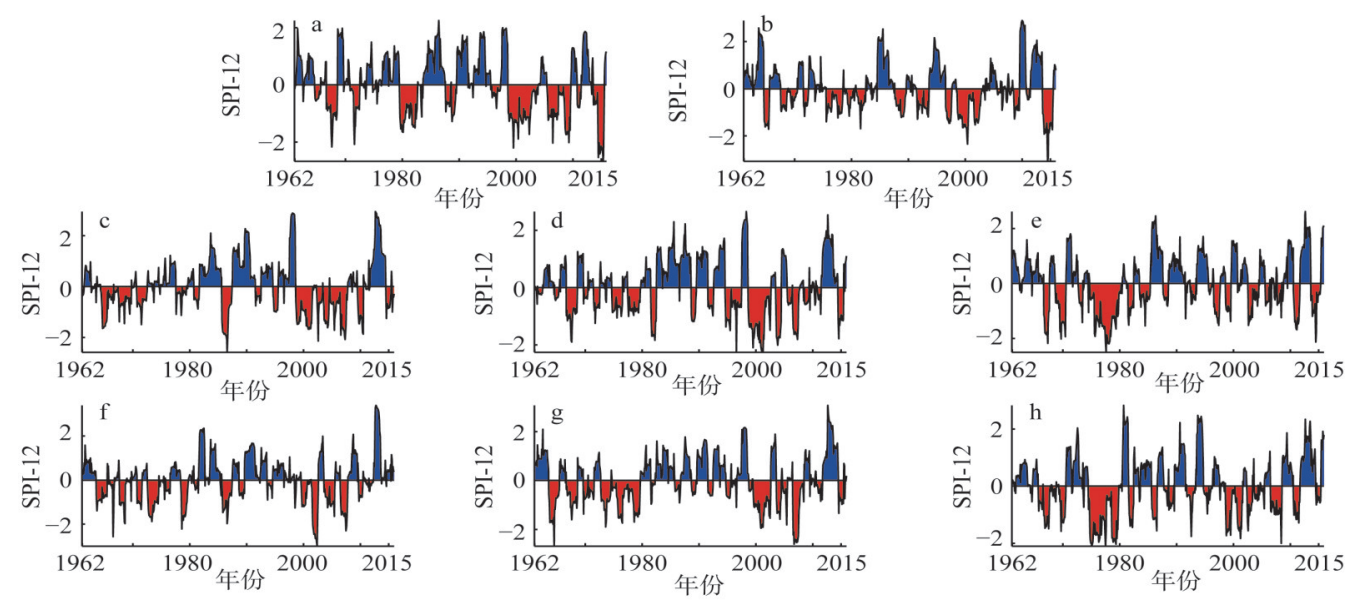

图 3 NEC气候亚区 SPI-12 时间序列

Fig. 3 Temporal evolution of regional average SPI-12 for the sub-climatic regions in Northeast China

区，1980s 以前中旱事件发生频繁，1980s 至 1990s 中期为主要的湿润期，1995-2011年为 该区最严重的干旱期。1998年和2013 年特大洪水对该区域影响显著。V 区干湿事件交替 频繁，尤其是 1980s 中期以后，最严重的干旱发生在 1960s 后期至 1980s 初期。VI区经历 了 1965-1980 年的干旱期、1981-1999年的湿润期、2000-2008 年的干旱期以及 2008年以 后的相对湿润期。该区持续时间较短的干旱事件较多，1998 年特大洪水对该区影响不 大。VII 区与其相邻 IV 区干湿交替情况具有很大的相似性，例如以中轻早为主，1980s 和 1990s 湿润事件多于干旱事件的发生，21 世纪出现了严重的干旱。但是，也有一些差 异, IV 区平均干旱历时和平均干旱烈度均超过 VII 区。VII 区和 V 区的干湿演变历程也是相 似的，只不过 V 区比VIII区的干湿交替更加频繁，但VIII 区干旱事件的平均干旱历时和干旱 烈度均大于 $V$ 区。

上述表明：（1）NEC不同气候亚区的干湿事件时间演变模式存在差异。其中，II 区与 其它亚区差异明显；IV 区和VII 区、V 区和VIII 区具有相似的干湿交替过程，但它们在不同时 间段上干湿事件的历时和程度仍有所差异。（2）各亚区大致都经历了三个干旱时期 ${ }^{[27]}$ : 1960s 后期、1970s 中后期至 1980s 初期、1990s 后期至2000s。（3）2000-2010年间 NEC干 旱发生频率和影响范围最大，尤其是 NEC 的 I 区、III 区、IV区和VII区。

\subsection{NEC 气候亚区干旱的周期特征}

为了进一步探索 NEC 近 55 年来不同气候亚区干早的年际及年代际变化特征，分别对 各亚区的 SPI-12 时间序列作 Morlet 小波变换，以确定 SPI-12 时间序列在不同时间尺度的 相对功率。图 4 为 8 个亚区的Morlet 小波功率谱及其小波全谱图，在小波功率谱图中，白 色粗实线表示显著性水平达到 $\alpha=0.05$ 的周期特征，黑色粗实线为影响雉。交叉线区域表 示该部分小波功率谱受到边缘效应的影响, 其周期特征存在较大不确定性。一般来说, 尺度越长, 边缘效应影响越大。在小波全谱图中, 当红噪声谱（细虚线）小于计算谱曲 线（细实线）时，表明该区段对应的周期特征达到了 $\alpha=0.05$ 显著性水平。

I 区 SPI-12 时间序列在 1970-2010年显示出 8 年左右的主振荡周期，其间嵌套着 2 4 年的变化周期，1968-1975 年、1988-2001 年间的 4 年振荡周期，2009-2014 年的 2 年振荡 
周期，第一主周期 6.9 年，第二主周期 3.9年。II 区 SPI-12 时间序列在 1977-2009年存在 着极强的 8 12 年的主震荡周期，1963-1969 年、2008-2013 年表现出 2 4 年的年际变化, 1985-1995 年呈现 4 6 年的变化周期，第一主周期 11 年，第二主周期 2.9 年。III 区 SPI-12 时间序列于 1980-2010 年表现出显著的4 8 年的主震荡周期，1985-1988 年和 1995-2000年 分别叠加着短暂的 3 年和 2 年左右的显著周期, 第一主周期 7.4 年, 第二主周期 4.9 年。 IV 区 SPI-12 时间序列在 1980-2010年主要存在 2 8 年的变化周期，第一主周期 3.7 年。V 区 SPI-12 时间序列在 1965-1973 年、2008-2013 年存在 2 4 年的振荡周期，1983-2000年存在 $3 \sim 6$ 年的变化周期，1973-1985 年显示 8 16 年的周期，第一主周期 3.1 年。VI区 SPI-12 时 间序列在 1975-1995 年以 6 10 年周期为主，其间嵌套 1.5 3 年的周期，2000-2014 年呈现 1.5 6 年的振荡周期，第一主周期 6.9 年，第二主周期 2.6 年。VII 区 SPI-12 时间序列在 1965-1975 年存在 3 年左右的振荡周期，1995-2010 年表现出 3 8 年的年际变化, 第一主周 期 4.9 年，第二主周期 3.3 年。VIII 区 SPI-12 时间序列于 1970-1995 年表现出 8 14 年的变化 周期，1977-2000 年、2005-2012 年存在着 2 4 年的振荡周期，第一主周期 10.4 年，第二 主周期 3.3 年。
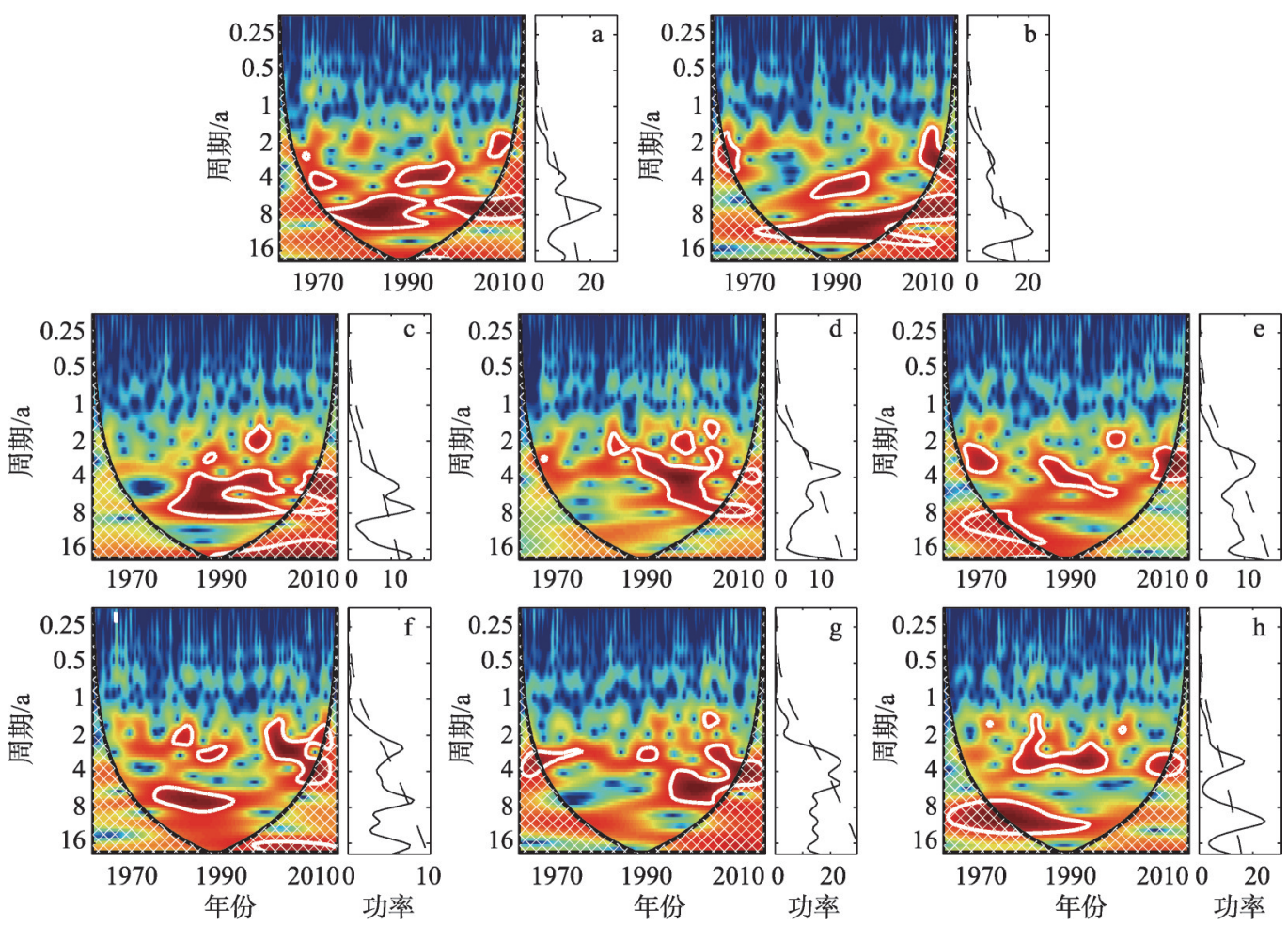

图4 各气候亚区 SPI-12 时间序列的Morlet 小波功率谱及其小波全谱图

Fig. 4 The wavelet power spectrum using Morlet mother wavelet and the global wavelet spectrum about the SPI-12 time series of the eight sub-climatic regions

以上结果表明：（1）不同气候亚区气象干旱的第一主周期不一致，具有明显的局部 化特征。如, 西部（ I 区、II 、 III 、VI区）和东部（VIII区）亚区的第一主周期较 长，中部（IV 区、V 区、VII区）亚区的第一主周期较短；（2）各气候亚区大都嵌套着 3.5 年左右的主周期。 


\section{3 结论与讨论}

\section{1 结论}

（1）利用1961-2016年中国地面降水和气温月值 $0.5^{\circ} \times 0.5^{\circ}$ 格点数据，借助空间系统聚 类法将 NEC 划分为具有明确界线的 8 个亚区，即：西辽河平原半干旱农牧区（I）、吉辽 东部山地湿润农林区（II ）、呼伦贝尔高原半干旱牧业区（III）、东北中部半湿润一半干 旱农牧区（IV)、黑吉东部山地湿润农林区（V)、大兴安岭北部湿润林业区（VI）、呼伦 贝尔一黑河湿润一半湿润农林区（VII）、三江平原湿润农业区（VIII）。

(2) NEC 不同亚区的干旱事件时间演变特征存在差异，但大致均经历了三个干旱时 期：1960s 后期、1970s 中后期至 1980s 前期和 1990s 后期至2000s。2000-2010年间 NEC 干 旱发生频率和影响范围最大，尤其是 NEC 的中、西部。

(3) 不同亚区干早变化主要存在 11 年和 3 8 年的显著周期，第一主周期差异明显。

\section{2 讨论}

\section{2 .1 与其他学者分区方法和结果的对比}

近 50 年来 NEC 干早化趋势明显，越来越频繁的干旱事件对该区域人民的生产和生活 造成了严重的影响 ${ }^{[2-5]}$ 。 NEC 地貌复杂, 地理范围跨经纬度较大以及天气系统影响不同, 使得气候条件和敏感性在不同的区域差异很大，将 NEC 作为单一的研究对象或者应用传 统的地理边界进行气象干旱研究显得过于粗放。因此，为了弄清楚每个亚区特有的气候 变化驱动因素，有必要依据气候变量将 NEC 进行空间细分。孙力等 ${ }^{[7]}$ 、李明等 ${ }^{[9]}$ 和高西宁 等 ${ }^{[10]}$ 采用旋转正交函数分解 (REOF) 方法，分别利用夏季降水量、年降水量和标准化降 水蒸散指数对 NEC 进行了气候分区的研究。但是由于 REOF 是一种经验的方法，在确定 亚区边界上存在着一定的主观性和模糊性。孙滨峰等 ${ }^{[8]}$ 采用主成分聚类分析方法，结合气 象站逐月降水数据将 NEC 分成了 8 个气候亚区，分区结果与本文相似。但是，由于孙滨 峰等 ${ }^{[8]}$ 用的是气象站点数据，那么在亚区最终界线的确定上也存在着主观性。

依据郑景云等 ${ }^{[28]}$ 中国气候区划的结果，东北中部和西部分别属于半湿润地区和半干 旱地区 (IV 区)。而孙力等 ${ }^{[7]}$ 、孙滨峰等 ${ }^{[8]}$ 、高西宁等 ${ }^{[10]}$ 和徐一丹等 ${ }^{[29]}$ 学者虽然所用分区方 法与本文不同，但结果均将它们划分在一起，其中孙力等 ${ }^{[7]}$ 和高西宁等 ${ }^{[10]}$ 划分的 IV 区范围 与本文基本一致，孙滨峰等 ${ }^{[8]}$ 和徐一丹等 ${ }^{[29]}$ 的 IV 区范围大于本文结果。尽管东北中部和西 部在降水量和生态环境条件上差异较大，但该区域年降水量和年均温的年际变率可能具有 相似性。因此，本文尝试将 NEC 划分为不同数量的气候亚区（图 5)，结果表明：NEC分 成 4 9个亚区时，IV 区的范围未曾发生变化，直至 15 个亚区时，IV 区才被分成 5、6、7三 部分（图 51）。可见 5、6、7 三个亚区年降水量和年均温年际变化的相关系数是较大的, 故上述结果在一定程度上也说明当 NEC 划分少于 9 个气候亚区时, 将吉林省和黑龙江省 的中西部及内蒙古的兴安盟划分在一起，具有合理性。再者，IV 区属于松花江流域，将 其划为一个亚区，在制定气候区域干早监测计划时，便于统一协调水资源的配置。另 外, 孙力等 ${ }^{[7] 、}$ 孙滨峰等 ${ }^{[8]}$ 、高西宁等 ${ }^{[10]}$ 和徐一丹等 ${ }^{[29]}$ 学者也将降水量较少的延吉盆地和 珲春盆地与降水量较多的长白山中心区分在了同一个区域，只不过区域范围与本文 $\mathrm{V}$ 区 结果有所差异，可能原因同 IV 区。再者，从地貌看，V区整体上属于长白山地区。

3.2.2 $\mathrm{NEC}$ 气候亚区干早的时间变化

徐一丹等 ${ }^{[29]}$ 和高蓓等 ${ }^{[30]}$ 的研究结果均表明 $\mathrm{NEC}$ 气象干旱存在明显的阶段性特征, 


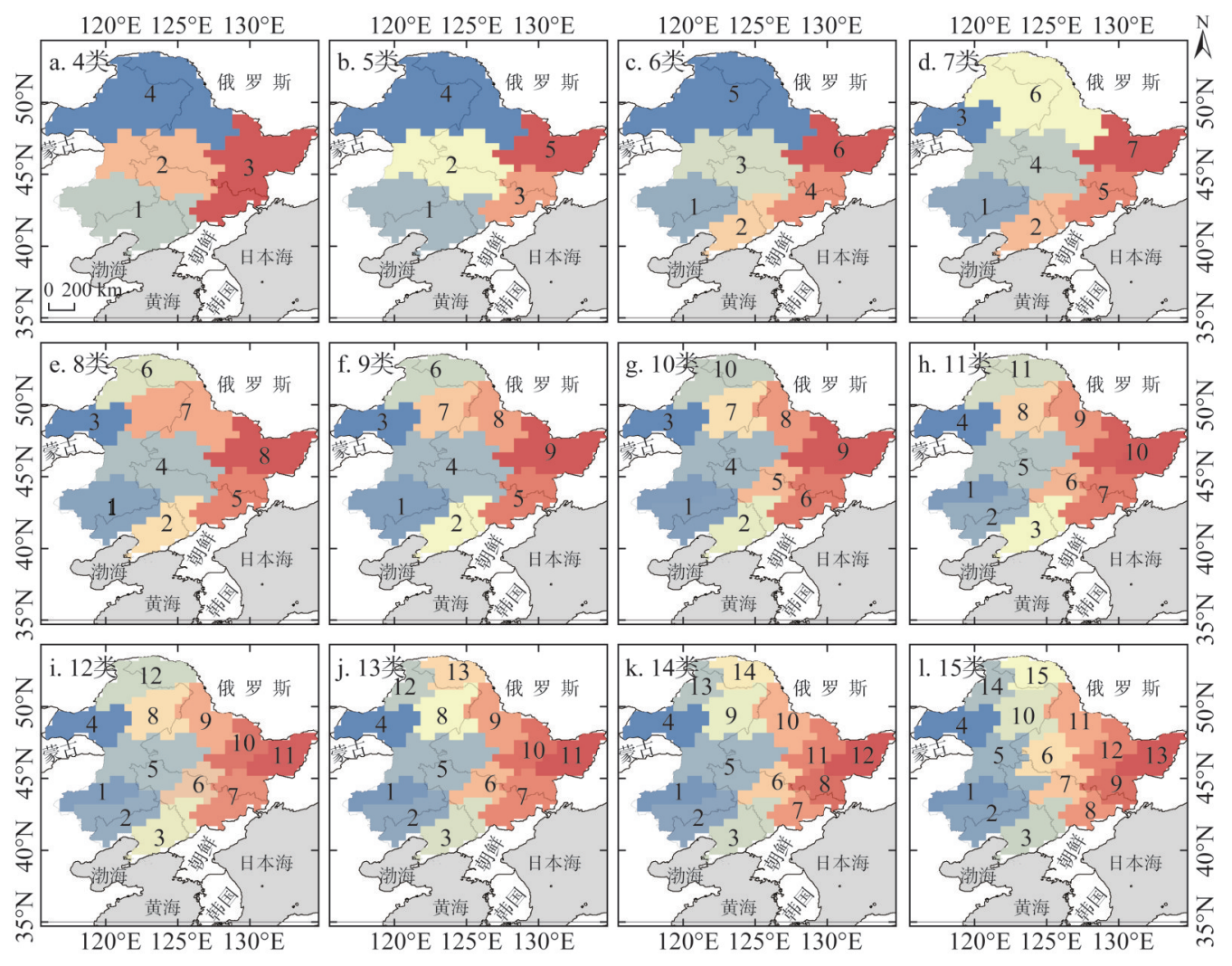

图 5 不同聚类数方案的东北气候分区结果

Fig. 5 Climate regionalization with different clustering schemes in Northeast China

1960s 末、1970s 后期和 1990s 后期至 2000s 时间段内发生了连续干早，与本文的结论基本 一致。马建勇等 ${ }^{[3]}$ 基于 SPI 指数分析却认为 NEC1961-1975 年为偏涝期，胡娜娜 ${ }^{[31]}$ 也持同 样的观点。之所以出现这样的差异, 可能是由于不同学者使用的数据源及截取数据的时 间区间不同造成的。另外，不同学者因使用数据、采用方法的差异，对于 NEC气象干旱 周期特征的检测结果亦存在较大的差异。如，卢洪健等 ${ }^{[27]}$ 通过小波分析发现 NEC气象干 旱周期具有明显的空间差异，南部干旱的第一主周期为 11 年左右，北部则为 3.5 年左 右。马建勇等 ${ }^{[3]}$ 研究表明 NEC 1961-2009年生长季期间的气象干旱存在 22 年的主周期。 但以上学者对于 NEC 干旱主周期的检测结果未进行显著性检验。孙莹等 ${ }^{[32]}$ 使用 NEC 夏季 气温数据，通过功率谱方法仅检测到明显的 3 年周期变化。本文研究结果表明 NEC 不同 亚区干旱变化的第一主周期差异明显，主要存在 11 年和 3 8 年的显著周期。11 年的长周期 与太阳黑子活动的准周期基本一致，3 8 年的短周期反映了厄尔尼诺一南方涛动（ENSO） 事件影响下的 NEC 各亚区干旱的变化过程 ${ }^{[33-35]}$ 。因此, 利用滑动相关系数、交叉小波谱 和小波相干方法研究ENSO、太阳黑子活动、太平洋副热带高压、东亚夏季季风环流与 $\mathrm{NEC}$ 干早之间的关联性和响应特征，进一步解释 NEC 不同气候亚区在干旱时间变化方面 异同性的机理，将会是下一步研究的重点内容。另外，由于 SPI值的计算仅考虑了降水 这一个因素，对气温、风速、蒸发、连续无雨日数等与干旱有关的气象因子未考虑在 内, 故对 NEC 的气象干旱特征有待更深人的研究。 


\section{参考文献(References):}

[1] 沈永平, 王国亚. IPCC第一工作组第五次评估报告对全球气候变化认知的最新科学要点. 冰川冻土, 2013, 35(5): 1068-1076. [SHEN Y P, WANG G Y. Key findings and assessment results of IPCC WGI Fifth Assessment Report. Journal of Glaciology and Geocryology, 2013, 35(5): 1068-1076.]

[2] 孙永罡, 白人海, 谢安. 中国东北地区干旱趋势的年代际变化. 北京大学学报: 自然科学版, 2004, 40(5): 806-813. [SUN Y G, BAI R H, XIE A. Interdecadal variations of droughts in Northeastern China. Acta Scientiarum Naturalium Universitatis Pekinensis, 2004, 40(5): 806-813.]

[3] 马建勇, 许吟隆, 潘婕. 基于 SPI 与相对湿润度指数的 1961-2009年东北地区 5-9 月干旱趋势分析. 气象与环境学报, 2012, 28(3): 90-95. [MA J Y, XU Y L, PAN J. Drought tendency based on standardized precipitation index (SPI) and relative moisture index over Northeast China from May to September during 1961-2009. Journal of Meteorology and Environment, 2012, 28(3): 90-95.]

[4] 邹旭恺, 任国玉, 张强. 基于综合气象干旱指数的中国干旱变化趋势研究. 气候与环境研究, 2010, 15(4): 371-378. [ZOU X K, REN G Y, ZHANG Q. Droughts variations in China based on a compound index of meteorological drought. Climatic and Environmental Research, 2010, 15(4): 371-378.]

[5] 马柱国, 华丽娟, 任小波. 中国近代北方极端干湿事件的演变规律. 地理学报, 2003, 58(s1): 69-74. [MA Z G, HUA L J, REN X B. The extrem dry/wet events in Northern China during recent 100 years. Acta Geographica Sinica, 2003, 58 (s1): 69-74.]

[6] 沈国强, 郑海峰, 雷振锋. 基于 SPEI 指数的 1961-2014年东北地区气象干旱时空特征研究. 生态学报, 2017, 37(17): 5882- 5893. [SHEN G Q, ZHENG H F, LEI Z F. Spatiotemporal analysis of meteorological drought (1961-2014) in Northeast China using a standardized precipitation evapotranspiration index. Acta Ecologica Sinica, 2017, 37(17): 5882-5893.]

[7] 孙力, 安刚, 丁立. 中国东北地区夏季旱涝的分析研究. 地理科学, 2002, 22(3): 311-316. [SUN L, AN G, DING L. The characteristics of summer drought and flood in Northeast Area of China. Scientia Geographica Sinica, 2002, 22(3): 311-316.]

[8] 孙滨峰, 赵红, 王效科. 基于标准化降水蒸发指数(SPEI)的东北干旱时空特征. 生态环境学报, 2015, 24(1): 22-28. [SUN B F, ZHAO H, WANG X K. Spatiotemporal characteristics of drought in Northeast China based on SPEI. Ecology and Environmental Sciences, 2015, 24(1): 22-28.]

[9] 李明, 王贵文, 张莲芝. 基于 SPEI 的中国东北地区干旱分区及其气候特征分析. 干旱区资源与环境, 2016, 30(6): 6570. [LI M, WANG G W, ZHANG L Z. Drought characteristics analysis and the zoning based on standardized precipitation evapotranspiration index in Northeast China. Journal of Arid Land Resources and Environment, 2016, 30(6): 65-70.]

[10] 高西宁, 蒋姗姗, 王䇯, 等. 东北地区 1961-2014年降水量变化分区及其区域特征. 生态学杂志, 2016, 35(5): 13011307. [GAO X N, JIANG S S, WANG S, et al. The division of precipitation change and its regional characteristics in Northeast China during 1961-2014. Chinese Journal of Ecology, 2016, 35(5): 1301-1307.]

[11] 董蕾, 张明军, 王圣杰, 等. 基于格点数据的西北干旱区极端降水事件分析. 自然资源学报, 2014, 29(12): 2048-2057. [DONG L, ZHANG M J, WANG S J, et al. Extreme precipitation events in arid areas in Northwest China based on gridded data. Journal of Natural Resources, 2014, 29(12): 2048-2057.]

[12] 赵显飞, 朱江, 许舥. 近 $50 \mathrm{a}$ 中国降水格点数据集的建立及质量评估. 气象科学, 2014, 34(4): 414-420. [ZHAO Y F, ZHU J, XU Y. Establishment and assessment of the grid precipitation datasets in China for recent 50 years. Journal of the Meteorological Sciences, 2014, 34(4): 414-420.]

[13] 马须, 张勃, 周丹, 等. 基于标准化降水蒸散指数的中国东部季风区干旱特征分析. 自然资源学报, 2016, 31(7): 11851197. [MA B, ZHANG B, ZHOU D, et al. Analysis of drought characteristics of the East China monsoon area based on standardized precipitation evapotranspiration index. Journal of Natural Resources, 2016, 31(7): 1185-1197.]

[14] BADR H S, DEZFULI A K, ZAITCHIK B F, et al. Regionalizing Africa: Patterns of precipitation variability in observations and global climate models. Journal of Climate, 2016, 29(24): 9027-9043.

[15] MCKEE T B, DOESKEN N J, KLEIST J. The relationship of drought frequency and duration to time scales. In: Proceedings of the Eighth Conference on Applied Climatology. Boston: American Meteorological Society, 1993: 179-184.

[16] 张强, 邹旭恺, 肖风劲, 等. 气象干旱等级(GB/T 20481-2006). 北京: 中国标准出版社, 2006: 14-15. [ZHANG Q, ZOU X K, XIAO F J, et al. Classification of Meteorological Drought (GB/T 20481-2006). Beijing: Standard Press of China, 2006: 14-15.] 
[17] PAULO A A, PEREIRA L S. Stochastic prediction of drought class transitions. Water Resources Management, 2008,22 (9): 1277-1296.

[18] GOCIC M, TRAJKOVIC S. Analysis of precipitation and drought data in Serbia over the period 1980-2010. Journal of Hydrology, 2013, 494: 32-42.

[19] BONACCORSO B, BORDI I, CANCELLIERE A, et al. Spatial variability of drought: An analysis of the SPI in Sicily. Water Resources Management, 2003, 17(4): 273-296.

[20] RAZIEI T, SAGHAFIAN B, PAULO A A, et al. Spatial patterns and temporal variability of drought in Western Iran. Water Resources Management, 2009, 23(3): 439-455.

[21] GRINSTED A, MOORE J C, JEVREJEVA S. Application of the cross wavelet transform and wavelet coherence to geophysical time series. Nonlinear Processes in Geophysics, 2004, 11(5/6): 561-566.

[22] 刘永婷, 徐光来, 尹周祥, 等. 全球变化背景下安徽近 $55 \mathrm{a}$ 气温时空变化特征. 自然资源学报, 2017, 32(4): 680-691. [LIU Y T, XU G L, YIN Z X, et al. Spatio-temporal change of surface air temperature in Anhui province in the context of global warming from 1960 to 2014. Journal of Natural Resources, 2017, 32(4): 680-691.]

[23] 龚强, 汪宏宇, 王盘兴, 等. 东北夏季降水年代际、年际变化的区域差别. 气象科学, 2007, 27(6): 672-678. [GONG Q, WANG H Y, WANG P X, et al. Regional differences of summer rainfall interdecadal and interannual variations in the Northeast China. Journal of the Meteorological Sciences, 2007, 27(6): 672-678.]

[24] 祁海霞, 智协飞, 白永清. 中国干旱发生频率的年代际变化特征及趋势分析. 大气科学学报, 2011, 34(4): 447-455. [QI H X, ZHI X F, BAI Y Q. Interdecadal variation and trend analysis of the drought occurrence frequency in China. Transactions of Atmospheric Sciences, 2011, 34(4): 447-455.]

[25] 孙凤华, 杨素英, 陈鹏狮. 东北地区近 44 年的气候暖干化趋势分析及可能影响. 生态学杂志, 2005, 24(7): 751-755. [SUN F H, YANG S Y, CHEN P S. Climatic warming-drying trend in northeastern China during the last 44 years and its effects. Chinese Journal of Ecology, 2005, 24(7): 751-755.]

[26] 邹立尧, 国世友, 牛宁. 三江平原 1960-2004 年农业气候环境年代际变化. 地球科学进展, 2010, 25(8): 844-850. [ZOU L Y, GUO S Y, NIU N. Interdecadal change of agroclimatic environment in Sanjiang Plain during 1960-2004. Advances in Earth Science, 2010, 25(8): 844-850.]

[27] 卢洪健, 莫兴国, 孟德娟, 等. 气候变化背景下东北地区气象干旱的时空演变特征. 地理科学, 2015, 35(8): 10511059. [LU H J, MO X G, MENG D J, et al. Analyzing spatiotemporal patterns of meteorological drought and its responses to climate change across Northeast China. Scientia Geographica Sinica, 2015, 35(8): 1051-1059.]

[28] 郑景云, 尹云鹤, 李炳元. 中国气候区划新方案. 地理学报, 2010, 65(1): 3-12. [ZHENG J Y, YIN Y H, LI B Y. A new scheme for climate regionalization in China. Acta Geographica Sinica, 2010, 65(1): 3-12.]

[29] 徐一丹, 任传友, 马熙达, 等. 基于 SPI/SPEI 指数的东北地区多时间尺度干旱变化特征对比分析. 干旱区研究, 2017, 34(6): 1250-1262. [XU Y D, REN C Y, MA X D, et al. Change of drought at multiple temporal scales based on SPI/SPEI in Northeast China. Arid Zone Research, 2017, 34(6): 1250-1262.]

[30] 高菩, 姜粀, 苏布达, 等. 基于 SPEI 的 1961-2012 年东北地区干旱演变特征分析. 中国农业气象, 2014, 35(6): 656662. [GAO B, JIANG T, SU B D, et al. Evolution analysis on droughts in Northeast China during 1961-2012 based on SPEI. Chinese Journal of Agrometeorology, 2014, 35(6): 656-662.]

[31] 胡娜娜. 东北三省旱涝时空演变及趋势判断. 西安: 陕西师范大学, 2013. [HU N N. Time and space evolution and trend judgment of drought and flood in three northeastern provinces. Xi'an: Shaanxi Normal University, 2013.]

[32] 孙芗, 江静, 杨青, 等. 东北夏季气温分区变化特征. 气象科学, 2008, 28(1): 50-55. [SUN Y, JIANG J, YANG Q, et al. Variability of summer temperature in the three subregions of Northeast China. Journal of the Meteorological Sciences, 2008, 28(1): 50-55.]

[33] LIU X, XU Z, YU R. Spatiotemporal variability of drought and the potential climatological driving factors in the Liao River Basin. Hydrological Processes, 2012, 26(1): 1-14.

[34] HAN T, WANG H, SUN J. Strengthened relationship between Eastern ENSO and summer precipitation over Northeastern China. Journal of Climate, 2017, 30(12): 4497-4512.

[35] WU R, YANG S, LIU S, et al. Changes in the relationship between Northeast China summer temperature and ENSO. Journal of Geophysical Research: Atmospheres, 2010, 115(D21107): 1-15. 


\title{
Climate regionalization and temporal evolution of meteorological drought in Northeast China based on spatial clustering
}

\author{
LI Ming ${ }^{1,2,3}$, WANG Gui-wen ${ }^{1}$, CHAI Xu-rong ${ }^{1}$, HU Wei-xia ${ }^{4}$, ZHANG Lian-zhi ${ }^{1}$ \\ (1. School of Geographical Sciences, Shanxi Normal University, Linfen 041000, Shanxi, China; 2. Modern \\ College of Arts and Sciences, Shanxi Normal University, Linfen 041000, Shanxi, China; 3. Laboratory of \\ Remote Sensing and Climate Information, Shanxi Normal University, Linfen 041000, Shanxi, China; \\ 4. College of History and Tourism Culture, Shanxi Normal University, Linfen 041000, Shanxi, China)
}

\begin{abstract}
In the past 50 years, an increasing number of drought events have greatly affected the production and life of the people in Northeast China (NEC). The climatic conditions and sensitivities vary greatly in NEC due to complex terrain, large geographical range across latitudes and longitudes and different weather system effects. So, NEC is used to explore traditional geographical boundaries for meteorological drought research. In the paper, climate regionalization is performed by spatial hierarchical cluster approach based on the gridded dataset of monthly precipitation and temperature with a spatial resolution of $0.5^{\circ} \times 0.5^{\circ}$ in China from 1961 to 2016. Then, standardized precipitation index is employed to explore the temporal evolution of drought events, and wavelet method is used to detect drought periodicity in each sub-climatic region of NEC. The results show that: (1) Spatially, NEC can be divided into eight sub-climatic regions, namely, semi-arid agro-pastoral areas in the West Liaohe Plain, humid agro-forestry areas in the eastern mountainous areas of Jilin and Liaoning provinces, semi-arid pastoral areas in Hulun Buir Plateau, semi-humid and semi-arid agro-pastoral areas in central Northeast China, humid agro-forestry areas in the eastern mountainous areas of Heilongjiang and Jilin provinces, humid forestry areas in the north of Da Hinggan, humid and semi-humid agro-forestry areas in Hulun Buir Plateau and Heihe, and humid agricultural areas in Sanjiang Plain. (2) There are obvious differences for the temporal evolution of drought events in different sub-climatic regions, but three obvious drought periods, namely, late 1960s, late 1970s to early 1980s, and late 1990 s to 2000 s, can be found in each sub-region. The frequency and impact of droughts in NEC were the largest between 2000 and 2010, especially in the central and western parts of the study region. (3) There are significant drought periods of 11 years and 3- 8 years in the eight sub-climatic regions of NEC, and the first main cycles of drought variation are not completely consistent. It is a very important step to divide a region into homogeneous sub-regions based on one or more climatic variables in climate studies. Therefore, the results of this paper have practical significance for identifying the drivers of climate variability specific to each sub-climatic region, establishing drought monitoring programs for climate homogeneous regions and managing water resources.
\end{abstract}

Keywords: climate regionalization; meteorological drought; standardized precipitation index; spatial hierarchical cluster approach; wavelet analysis 